\title{
ŻYCIE SPOLECZNE W KONTEKŚCIE MIGRACYJNYM. PARAFIA JAKO OŚRODEK ŻYCIA RELIGIJNO-SPOLECZNEGO POZA GRANICAMI POLSKI
}

Polska od lat ma ujemne saldo migracyjne. Poza granicami naszego kraju żyje około 20 milionów Polaków i osób o polskich korzeniach. W tej grupie znajduje się ponad dwa miliony tzw. migrantów poakcesyjnych, którzy wyjechali po przystąpieniu Polski do Unii Europejskiej w 2004 roku. Przedmiotem mojego zainteresowania będzie wskazanie roli, jaką dla życia społecznego migrantów odgrywa Kościół katolicki, poprzez organizowane na poziomie parafii życie religijne oraz społeczno-kulturowe. Jego szczególna rola w odniesieniu do wcześniejszych fal migracji związana była z czasami zaborów, a później komunistycznego reżimu, którego represje i towarzysząca im ekonomiczna stagnacja sprzyjały wyjazdom z Polski. W tej sytuacji Kościół (działające za granicą parafie, polscy księża, prowadzone przez Polaków wspólnoty i stowarzyszenia działające przy kościołach) przejmował w pewnym sensie instytucjonalne role państwa, zwłaszcza jego socjalne i organizacyjne funkcje, świadcząc uchodźcom politycznym różne formy pomocy i wsparcia religijnego i pozareligijnego. Należy pamiętać, że wsparcie to może mieć postać zarówno podtrzymującą religijną czy też, szerzej, narodową tożsamość, jak i zmierzające w kierunku kulturowej adaptacji i asymilacji w kraju przebywania migranta ${ }^{1}$.

Dr hab. JAKUB IsAŃSKI - adiunkt Instytutu Socjologii w Uniwersytecie im. Adama Mickiewicza w Poznaniu; e-mail: isan@amu.edu.pl

${ }^{1}$ Szerzej proces ten opisują socjologowie amerykańscy, A. Portes i R.G. Rumbaut (Immigrant America. A Portrait, Los Angeles-London 2006), identyfikując rolę kościołów różnych wyznań, działających na terenie Stanów Zjednoczonych, w inkorporacji przedstawicieli migracji do życia społeczno-kulturowego w miejscu swojego nowego przebywania z utrzymywaniem więzi z krajem swojego pochodzenia. 
Wspomniana migracja poakcesyjna ostatnich lat ma zupełnie inny charakter od wcześniejszych fal migracyjnych. Chociaż nie budzi wątpliwości jej dobrowolność, to ekonomiczne czynniki stymulujące wyjazdy, zwłaszcza wśród młodych, w pierwszych latach po unijnej akcesji, mogą być traktowane jako forma desperacji podobna do tej, jaka popychała Polaków do wyjazdów w latach 80 . XX wieku. Jedną z istotnych różnic najnowszych migracji w stosunku do jej wcześniejszych fal jest utrzymywanie stałych więzi z krajem pochodzenia, związane zarówno z rozwojem technik informacyjno-komunikacyjnych, jak i znacznym obniżeniem kosztów transportu (w tym także dzięki rozwojowi rynku tanich usług lotniczych). Więzi te, znacznie częściej niż przed laty, oparte są na indywidualnych kontaktach pomiędzy Polakami, często o podobnym miejscu (regionie) pochodzenia. Odnaleźć tutaj można elementy migracji opisywanej w literaturze przedmiotu jako „łańcuchowa" - oparta o więzi rodzinne lub etniczne na etapie przygotowania wyjazdu (wyboru miejsca), przygotowania miejsca pracy, mieszkania etc. Ciekawy problem dotyczy miejsca kościelnych instytucji we wspomnianym łańcuchu - poprzez parafie $^{2}$, instytucje i stowarzyszenia $\mathrm{w}$ adaptacji, a następnie integracji migrantów w nowym miejscu. Integracja ta ma nie tylko religijny charakter i odbywa się nie tylko w miejscach celebrowania kultu religijnego - nabożeństw i mszy św. Jego istotą wydaje się często wspólnota, niekoniecznie oparta na podzielanych przekonaniach religijnych, ale raczej wspólnym pochodzeniu etnicznym, które jest pretekstem, a zarazem legitymacją pojawiania się w określonych miejscach i godzinach, gdzie można spotkać innych Polaków.

Migracja, jako sytuacja nowa dla samych migrantów, związana jest z szeregiem wyzwań dotyczących różnych wymiarów życia tak samego migranta, jak i jego rodziny, oraz więzi z innymi osobami. Migracja często analizowana jest w literaturze przedmiotu jako sytuacja stanowiąca zagrożenie dla trwałości rodziny, w tym ryzyko jej rozpadu w wyniku wyjazdu jednego z członków rodziny lub obydwojga $^{3}$, lub też dynamikę życia rodziny związaną z wpływem doświadczeń

2 Parafia oraz poczucie więzi z nią wśród Polaków (w Polsce) była przedmiotem wielu badań socjologicznych, w których starano się określić zakres i listę wskaźników składających się na wspomnianą więź. W badaniu Instytutu Statystyki Kościoła Katolickiego z 2013 roku wymienia się na przykład: „Subiektywne poczucie związku laikatu z parafią; behawioralne przejawy związku osób świeckich z parafią; przynależność do wspólnot (grup) religijnych na terenie parafii; opinie o efektywności parafialnej działalności charytatywnej; Aktualna i potencjalna partycypacja osób świeckich w decydowaniu o sprawach parafialnych" (E. FIRLIT, Wspólnotowy wymiar religijności, w: Postawy społeczno-religijne Polaków 1991-2012, red. L. Adamczuk, E. Firlit, W. Zdaniewicz, Warszawa 2013, s. 126-127).

${ }^{3}$ Por. M. ОкóLSKI, Costs and benefits of migration for Central European countries, "CMR Working Papers" 2006, nr 7(65). 
emigracyjnych na małżonków ${ }^{4}$. Wsparcie, jakie mogą otrzymać migranci dzięki działalności parafii i funkcjonujących wokół niej pozareligijnych inicjatyw, może także przyczyniać się do utrudniania integracji w lokalnym środowisku w miejscu nowego zamieszkania. Przy braku znajomości języka migranci zagrożeni są, w dłuższej perspektywie czasowej, ograniczeniem swojej aktywności, tak zawodowej, jak i społecznej, do lokalnego środowiska, własnej grupy etnicznej, co ogranicza lub wręcz blokuje ich możliwości ruchliwości społecznej w górę ${ }^{5}$. Jest to tym bardziej istotne, gdy wyjazd migracyjny łączy się z ruchliwością społeczną w dół, co miało miejsce często zarówno wśród migrantów wyjeżdżających za granicę przed II wojną światową ${ }^{6}$, jak i występuje w najnowszych falach migracyjnych ${ }^{7}$.

Ramy działalności kościelnych instytucji w środowisku migracyjnym opisuje szereg dokumentów, by wymienić choćby instrukcję Erga migrantes caritas Christi, podkreślającą rolę opieki nad migrantami we współczesnym świecie zarówno ze strony duszpasterzy, jak i autochtonów. Zalecane w niej formy pomocy obejmują: miejsca wstępnego przyjęcia - domy migrantów, stołówki, sypialnie, ambulatoria, a także pomoc ekonomiczną ${ }^{8}$. Inna publikacja na ten temat zawiera wątki migracyjne w kazaniach papieża św. Jana Pawła II, które kierował do polskich migrantów w czasie swoich licznych pielgrzymek. W jednym z kazań z 1982 roku, jakie papież wygłosił do Polaków w Nigerii, padają bardzo ważne słowa o roli diaspory migracyjnej dla kraju jej pochodzenia w świecie, który jest opleciony siecią międzynarodowych połączeń: „Świat jest tak zorganizowany, że żaden naród nie żyje w całkowitej izolacji i byłoby chyba niedobrze, gdyby żył w całkowitej izolacji. Tak jak każdy człowiek z osobna żyje dla drugich, tak i narody żyją dla siebie i emigracja, jeżeli jest właściwie potraktowana, wedle odpowiednich przesłanek moralności społecznej, politycznej i międzynarodowej, jest wyrazem tego wzajemnego świadczenia społeczeństw i narodów wobec siebie"9.

Funkcjonowanie Polaków na emigracji od dawna było przedmiotem zainteresowania badaczy społecznych. Opisywane przez ojców-założycieli socjologii: Floriana Znanieckiego i Józefa Chałasińskiego wychodźstwo, migracja i zagraniczne wspól-

${ }^{4}$ Por. A. KwAK, Współczesne związi heteroseksualne, malżeństwa (dobrowolnie bezdzietne), kohabitacja, LAT, Warszawa 2014.

${ }^{5}$ Por. M. Sumption, W. Somerwille, The UK's New Europeans. Progress and challenges five years after accession, 2009 [online], http://www.migrationpolicy.org/research/uks-new-europeans-progress-and-challenges-five-years-after-accession; E. JAźwiŃSKA-MoTYLSKA (red.), Kariery i mobilność społeczno-zawodowa migrantów poakcesyjnych, „CMR Working Papers” 2013, $\mathrm{nr}$ 65(123).

${ }^{6}$ Por. H. JanowsKa, Emigracja zarobkowa z Polski 1918-1939, Warszawa 1981.

7 Por. I. Grabowska, M. OKólski, Emigracja ostatnia?, Warszawa 2009.

8 Papieska Rada ds. DuszPasterstwa MigRantów i PodróżująCyCh, Instrukcja Erga migrantes caritas Christi, 2004, s. 24-26.

9 Za: R. Dzwonkowski, Papiez Jan Pawet II. Misja Polonii i Emigracji, Warszawa 2016, s. 28. 
noty Polaków, od lat były związane z polskimi parafiami działającymi w różnych częściach świata. „Parafia zamyka się przed obcymi, chce zostać grupą swoich”10. Bogata jest również literatura przedmiotu w zakresie wspólnotowego potencjału parafii, by wymienić choćby analizę obszernych wyników badań realizowanych na początku drugiej dekady XXI wieku przez zespół badaczy związanych z Instytutem Statystyki Kościoła Katolickiego ${ }^{11}$. Dane deklaratywne zebrane na ogólnopolskiej próbie pokazały w nich, m.in., wysoki poziom poczucia identyfikacji z parafią - w 2012 roku deklarowało go 43,2\% respondentów, a kolejne 31,9\% wybrało odpowiedź: „tak, w pewnym stopniu” ${ }^{2}$.

Trudno jest określić liczbę parafii i ośrodków duszpasterskich działających poza granicami Polski. Na przykład w polskich parafiach katolickich w Stanach Zjednoczonych w 1918 roku zrzeszonych było 100 tys. osób ${ }^{13}$. Aktywność tych parafii zdecydowanie wykraczała poza religijne ramy; jak opisuje to jedna $\mathrm{z}$ autorek, Polacy uczestniczyli w ,paradach, wspólnych wydarzeniach, procesjach, demonstracjach, spotkaniach, konwencjach na wiele różnych okazji" ${ }^{14}$. Badacz polskiej emigracji, Florian Znaniecki pisał, iż udział w „towarzystwie” opartym na etnicznych więziach, nierzadko sięgających także regionu, a nawet miejscowości pochodzenia, zapewnia migrantowi poczucie wsparcia i bezpieczeństwa zarówno w codziennym życiu, jak i sytuacjach nadzwyczajnych, jak choroba, utrata pracy czy śmierćc ${ }^{15}$. O roli życia społecznego skupionego wokół parafii emigracyjnej w czasach Floriana Znanieckiego pisze Mary Erdmans: „tożsamość chłopskich migrantów była skupiona raczej wokół parafii czy też lokalnego regionu pochodzenia, niż wokół bardziej abstrakcyjnej koncepcji narodu. [...] Kiedy chłopi przybywali $\mathrm{w}$ porcie przyjazdu często odpowiadali na pytania o region pochodzenia wymieniając nazwy swoich wsi, parafię czy region"16. Autorka ta zaznacza wprawdzie dalej, że przedstawiciele inteligencji mieli bardziej wykształcone poczucie polskości i kulturową oraz polityczną tożsamość, jednak chłopi (zdecydowanie dominujący

10 Por. J. ChaŁasiński, Polonia amerykańska, w: F. Znaniecki, W. Thomas, Chłop polski w Europie i Ameryce, t. I: Organizacja grupy pierwotnej, Warszawa 1976, s. 13.

${ }^{11}$ Postawy spoleczno-religijne Polaków 1991-2012, red. L. Adamczuk, E. Firlit, W. Zdaniewicz, Warszawa 2013.

${ }^{12}$ E. FirLit, Wspólnotowy wymiar religijności, s. 135.

${ }^{13}$ Za: V. Granacki, Images of America. Chicagos Polish Downtown, Charleston 2004.

14 Tamże, s. 105.

15 Por. F. ZnANiecki, W. Thomas, Chłop polski, s. 35, 116. Wsparcie w sytuacjach nadzwyczajnych jest elementem budującym poczucie wspólnoty do dzisiaj, jako przykład można wymienić tutaj zbiórki pieniężne na transport zwłok zmarłego migranta do Polski, o którym wspomina wielu migrantów, por. J. IsAŃsKi, Migracje i transfery kapitału społecznego, Poznań 2015.

16 M.P. Erdmans, Opposite Poles. Immigrants and Ethnics in Polish Chicago 1976-1990, Pennsylvania 1998, s. 23. 
liczebnie w falach migracyjnych początków XX wieku) rozumieli polskość głównie w kategoriach językowych i religijnych. Pierwsza polska parafia w Chicago powstała w 1867 roku, od samego początku ogniskując życie nie tylko wokół religii, ale „całego życia Polaków”, co w praktyce oznaczało: szkoły podstawowe i średnie, sierocińce, szpitale, towarzystwa literackie, teatralne, chóry i koncerty, towarzystwa rekreacyjne i sportowe oraz inne stowarzyszenia, a także wydawanie gazet ${ }^{17}$; świadczono także różne formy pomocy osobom i rodzinom znajdującym się $\mathrm{w}$ potrzebie ${ }^{18}$. Więź z polskością była utrzymywana także poprzez celebrowanie kultu polskich świętych, a poznawanie historii ich życia było okazją do nauki historii Polski i polskiej kultury narodowej.

Socjologia jako nauka o społeczeństwie zajmuje się różnymi formami współpracy ludzi i warunkami sprzyjającymi nawiązywaniu tejże współpracy. Jej efektem może być powstawanie wspólnot, funkcjonujących na podstawie utrwalonych więzi definiowanych w wielu opracowaniach jako kapitał społeczny. Kategoria ta wykorzystywana była do przedstawienia korzyści, jakie z udziału we wspólnocie mogą mieć jej członkowie - dzięki podzielaniu wspólnego zestawu norm i wartości, dzięki współdziałaniu prowadzącemu do wzajemnego zaufania, ludzie są w stanie skutecznie podejmować rozmaite inicjatywy i mierzyć się z problemami przekraczającymi możliwości pojedynczego człowieka. Przykładem takiej zorganizowanej wspólnoty może być także społeczność parafialna ${ }^{19}$. Parafie jako jednostki terytorialne funkcjonują $\mathrm{w}$ ramach struktury Kościoła katolickiego. Ich funkcjonowanie (różne grupy, duszpasterstwa, charytatywne inicjatywy etc.) opiera się, w znacznej mierze, na założeniu o zamieszkiwaniu na danym obszarze pewnej stabilnej społeczności. Gromadzone w parafii dokumenty, by wspomnieć choćby księgi parafialne, są nierzadko okazją do prześledzenia wielowiekowej historii danej wsi, osiedla czy też regionu. Osobnym wyzwaniem są parafie funkcjonujące poza granicami Polski. Ich parafianie zazwyczaj nie stanowią równie stabilnej i trwałej struktury, a zwłaszcza ostatnie kilkanaście lat historii polskich migracji wyjazdowych dodatkowo dynamizuje społeczny wymiar działalności parafialnej,

${ }^{17}$ Porównanie tych form aktywności z dzisiejszymi przedstawia się następująco: w jednym $\mathrm{z}$ angielskich miast, w 2011 roku, licznie zamieszkiwanych przez przedstawicieli najnowszej polskiej migracji, angielscy badacze odnotowali ,3-30 tys. polskich firm i pracowników działających na własny rachunek, 12 polskich portali internetowych, 5 internetowych stacji radiowych, 20 polskich restauracji i sklepów z polską żywnością i produktami, polskie firmy rekrutujące pracowników, polski kościół, klub i sobotnia szkoła" (za: N. Vershinina, R. Barrett, M. Meyer, Forms of capital, intra-ethnic variation and Polish entrepreneurs in Leicester, „Work, Employment and Society” 2011, nr 25(1)); niedzielne nabożeństwa są także traktowane jako okazja do pochwalenia się nowym domem, pracą, samochodem, posłuchania ogłoszeń czy po prostu spotkania z rodakami i kontaktu z polskością.

18 Por. V. Granacki, Images of America; por. także A. Portes, R.G. Rumbaut, Immigrant America.

19 Por. W. SAdŁoń, Religijny kapitat spoteczny, Saarbrücken 2014. 
wprowadzając doń kontekst międzynarodowych i międzyreligijnych kontaktów tych parafian, którzy mają jakieś doświadczenia migracyjne ${ }^{20}$.

Parafia jest ośrodkiem życia, nie tylko religijnego, także w Polsce. Systematyczne badania społeczne prowadzone na ten temat pokazują różne formy działalności, jakie są w tym zakresie organizowane i z jakimi Polacy kojarzą parafie ${ }^{21}$. W badaniu na próbie ogólnopolskiej Centrum Badania Opinii Społecznej z 2014 roku wymieniano następujące formy działalności prowadzonej przy parafiach: organizowanie pielgrzymek do miejsc kultu w kraju i za granicą (odpowiednio: $73 \%$ i $59 \%$ odpowiedzi), pomoc dla najuboższych - 57\%, przygotowywanie strony internetowej parafii lub gazetki parafialnej (po 51\%), wyjazdy wakacyjne dla dzieci i młodzieży - 47\%, imprezy kulturalne (koncerty, wystawy, teatr, chór) oraz różne inne formy działalności dla młodzieży - po 39\%, imprezy sportowe i turystyczne $32 \%$, opiekę dla rodzin przeżywających trudności - 30\%, opiekę nad ludźmi starymi i niedołężnymi - 30\%. Ponadto, wokół parafii były także prowadzone inne formy działalności, jak: opieka nad dziećmi, opieka nad chorymi, hospicjum, pomoc dla bezrobotnych, wypożyczalnie książek, kluby emerytów i rencistów, porady medyczne, kawiarenki parafialne, kursy zawodowe, komputerowe i językowe ${ }^{22}$. Warto także zaznaczyć, że porównanie wyników badań z lat wcześniejszych pokazuje wzrost aktywności na polu większości wymienionych wyżej form aktywności, największy w pielgrzymkach do miejsc kultu za granicą (z poziomu 41\% w 1994 roku do 59\% w 2014), imprezach sportowych i turystycznych (wzrost z 18\% do $32 \%$ we wspomnianym okresie), a także w kategorii ,inne” - z 3\% w 1994 roku do $11 \% \mathrm{w} 2014$. W refleksji nad różnymi formami aktywności parafian skupionych wokół parafii nie należy jednak zapominać, że członkami różnych wspólnot jest relatywnie niewielki odsetek parafian; według badań CBOS w 2014 roku jedynie 9\% Polaków zadeklarowało, że należy do jakiejś wspólnoty religijnej, przy czym 8\% $\mathrm{w}$ swojej parafii, a $1 \% \mathrm{w}$ innej ${ }^{23}$, a więc czynnie uczestniczy w tworzeniu tejże aktywności. Wyższy jest za to odsetek parafian korzystających jedynie z oferowanych im różnych form aktywności, bez konieczności angażowania się w ich organizację i przygotowanie. I tak: z pielgrzymek do miejsc kultu w kraju korzystało $27 \%$ osób, $\mathrm{z}$ imprez kulturalnych (koncertów, teatrów, wystaw) - 17\%, z imprez sportowych i turystycznych $-10 \%$, a pozostałych form aktywności - mniejsze odsetki parafian. Łącznie około 43\% badanych deklaruje korzystanie z którejś z form aktywności

20 E. FirLIT, Wspólnotowy wymiar religijności, s. 142.

${ }^{21}$ Por. Parafia jako rzeczywistość wielowymiarowa, red. J. Baniak, Poznań 2003.

${ }^{22}$ CBOS, Spoleczna percepcja rzeczywistości parafialnej, oprac. N. Hipsz, 2014, https://www. cbos.p1/SPISKOM.POL/2014/K_163_14.PDF

${ }^{23} \mathrm{CBOS}$, Lokalna parafia - jej spoteczne znaczenie i funkcje, oprac. R. Boguszewski, 2014, https://www.cbos.pl/SPISKOM.POL/2014/K_158_14.PDF 
parafialnej, jednak - jak podsumowuje autor raportu - dla większości Polaków parafia jest swoistą ,instytucją usługową” o profilu działalności wykraczającym poza religię ${ }^{24}$. Przy czym wspomniane usługi świadczą zazwyczaj sami parafianie uczestniczący w różnych formach aktywności - w kategorii tej łącznie znajduje się niemal 1/3 parafian, w znakomitej większości jest to aktywność praktykowana „rzadko” lub „czasami”. Warto także zaznaczyć, że wśród odbiorców tej specyficznej oferty są nie tylko wierni mający regularny kontakt z parafią ${ }^{25}$.

Z kolei według danych zbieranych przez Instytut Statystyki Kościoła Katolickiego, w różnego rodzaju formach działalności prowadzonych przy parafiach zaangażowanych było w 2014 roku około 2675 tys. osób, przy czym liczba ta od roku 1998 do 2008 wzrosła o ponad $27 \%$, natomiast liczba organizacji i stowarzyszeń w tym samym czasie - o $51,5 \%{ }^{26}$. W. Sadłoń podaje wartość wskaźnika participantes - odsetka osób zaangażowanych w działalność w organizacjach wspólnotowych działających przy parafiach na poziomie $9,1 \%$, zaznaczając jednak, że jego rozkład w poszczególnych regionach kraju nie jest równomierny, a także fakt, iż wiele osób angażuje się w więcej niż jedną formę aktywności. Warto również przytoczyć tutaj jeszcze dwie informacje podawane przez tego autora: większość (61\%) religijnych organizacji wspólnotowych działa jedynie w obrębie danej parafii, co świadczy o lokalnym, oddolnym charakterze większości podejmowanych na terenie parafii form aktywności społecznej, a także, mimo iż stowarzyszeń świeckich - „regonowskich" jest więcej niż parafialnych, członkowie tych drugich spotykają się $\mathrm{z}$ większą regularnością. $\mathrm{W}$ innym raporcie o życiu parafialnym, przygotowanym przez ISKK oraz GUS, zamieszczono informację o deklarowanych problemach ograniczających działalność tych organizacji - na pierwszym miejscu znajduje się „brak członków” (27\% wskazań), dalej: „brak zainteresowania w parafii” (13\% wskazań) czy „brak wolontariuszy” (10\% wskazań); warto także dodać, że w niemal połowie przypadków (47\% odpowiedzi) pojawił się „brak problemów w funkcjonowaniu". Można tam także znaleźć informację o zadeklarowanych w statucie poszczególnych organizacji dziedzinach aktywności prowadzonych przy parafiach - na pierwszym miejscu wymieniana jest „religia” (w działalności 90\% organizacji), na kolejnych miejscach znajdują się: „edukacja i wychowanie” (wymienione w statutach $32 \%$ organizacji), „sport, turystyka, rekreacja i hobby”

24 Tamże.

25 Por. G. Gudaszewski, Dominicantes i communicantes - religijne praktyki niedzielne, w: Rocznik Statystyczny. Kościót katolicki w Polsce 1991-2011, red. zbior., Warszawa 2014.

26 Por. W. SAdloń, Religijny kapitat społeczny, s. 117-118; TENŻE, Kościelny trzeci sektor w Polsce oraz działalność charytatywna, w: Rocznik Statystyczny. 
(26\% organizacji), „kultura i sztuka” ( $24 \%$ organizacji) oraz „pomoc społeczna i humanitarna, ratownictwo" (wymienione w statutach $22 \%$ organizacji) ${ }^{27}$.

Analizując zatem charakter i znaczenie życia religijnego polskich migrantów współczesnych, chciałbym ponownie przypomnieć jego historyczną proweniencjędającą Kościołowi mandat zaufania u migrantów, jak i pewną praktykę ułatwiającą identyfikację potrzeb parafian-migrantów. Z drugiej strony, działalność Kościoła w środowisku migracyjnym w ostatnich latach uległa znacznemu przekształceniu, dostosowaniu do zmieniającego się charakteru migracji. Specyfika działalności polskich parafii za granicą zmienia się w ostatnich latach, inne są też potrzeby Polaków korzystających z różnych form tejże działalności. Parafianie rekrutują się z różnych form i okresów migracji, co wpływa na ich oczekiwania i potrzeby, które różnią się ze względu na kraj, w którym prowadzona jest działalność czy dominujący charakter poszczególnych fal migracyjnych przyjazdów. W Roczniku Statystycznym ${ }^{28}$ znajdujemy następującą typologię środowisk polonijnych, wśród których prowadzona jest działalność: (1) środowiska, w których Polacy mieszkają od wielu lat (w tym także od kilku pokoleń), stanowiąc mniejszości etniczne, do których dołączają kolejni migranci (np. w Stanach Zjednoczonych i Kanadzie); (2) środowiska, w których Polacy mieszkają od wielu lat, jednak nie ma dopływu kolejnych migrantów (np. w Ameryce Południowej); (3) środowiska Polaków mieszkających od wielu lat (a także pokoleń), do których przestali napływać nowi migranci (np. do RPA, Australii i Nowej Zelandii); (4) środowiska Polaków w krajach Europy Zachodniej z tzw. migracją poakcesyjną, która po rozszerzeniu Unii Europejskiej i przystąpieniu Polski do strefy Schengen jest obecnie najnowsza i bardzo liczna (należy dodać, że w większości z tych krajów również występują skupiska potomków wcześniejszych fal migracyjnych); (5) środowiska polskie powstałe w Irlandii i Islandii po rozszerzeniu UE i przystąpieniu Polski do strefy Schengen; (6) skupiska Polaków i potomków Polaków zamieszkujące kraje b. ZSRR i w byłych krajach tzw. demokracji ludowej, a także (7) „środowiska Polonii, emigracji polskiej i ludności niepolskiego pochodzenia, a posługujących się na co dzień językiem polskim (np. w Niemczech") ${ }^{29}$. Niezależnie od specyfiki miejsca, w którym prowadzona jest działalność, jak zaznacza W. Necel: „Ze względu na charakter płynności zjawiska migracji, organizacja duszpasterstwa migrantów winna być do charakteru tych zmian nieustannie dostosowywana"30. Różnica widoczna jest także na poziomie infrastruktury, jej własności i ponoszenia kosztów

${ }^{27}$ W. SADŁoŃ, Spoleczny potencjat parafii. Działalność przyparafialnych organizacji Kościoła katolickiego w Polsce w 2012 r., Warszawa 2014.

28 W. NeCEL, Katolickie duszpasterstwo na emigracji, w: Rocznik Statystyczny, s. 156-157.

${ }^{29}$ Tamże, s. 157.

30 Tamże. 
utrzymania, w liczbie wiernych przypadających na jednego duszpasterza (nierzadko jeden ksiądz lub osoba duchowna czy wolontariusz prowadzący jakąś działalność w ramach parafii pracuje w kilku miejscach), często w wynajmowaniu kościołów lub budynków. Dostęp migrantów do polskich parafii, bądź choćby polskich księży, zależy od kraju ich przebywania. Najwięcej ośrodków działa w krajach europejskich, szczególnie w krajach Europy Zachodniej, w której liczebność migrantów w ostatnich latach wzrosła i wielu z nich utrzymuje ożywione kontakty z krajem, często przy tej okazji korzystając np. ze ślubu, chrztu lub pogrzebu w Polsce mimo zamieszkiwania poza granicami kraju.

Na terenie Polski działa ponad 10 tysięcy parafii. Jak zostało wspomniane, trudne jest określenie liczby parafii działających poza granicami Polski, a kierujących swoją działalność do polskich migrantów. W większości przypadków działalność polskich parafii, misji i placówek prowadzona jest głównie w krajach, do których w ostatnich latach wyjechało najwięcej migrantów. Dla przykładu na terenie Wielkiej Brytanii jest to 90 misji katolickich i 200 miejsc, w których można uczestniczyć we mszy św. w języku polskim ${ }^{31}$, w innych krajach działa po kilkanaście takich ośrodków. Wiele z tych ośrodków prowadzonych jest przez zakony i duszpasterstwa migracyjne.

Należy podkreślić, że parafia poza granicami kraju oraz powstająca przy niej wspólnota, o dość płynnym często składzie, pełni rolę daleko wykraczającą poza pierwotne funkcje religijne, będąc dla wielu uczestników-migrantów swoistą platformą kontaktu z rodakami, nawiązywania kontaktów społecznych, ale i załatwiania bieżących spraw, jak znalezienie pracy, mieszkania czy opiekunki dla dziecka. Chociaż takie traktowanie Kościoła nie wyróżnia polskich migrantów spośród innych diaspor migracyjnych organizujących obecnie swoje życie społeczne w jednym z krajów Europy Zachodniej, warto także pamiętać, że jest ono dodatkowo wzmacniane przez historyczne znaczenie Kościoła, który tę rolę - animatora alternatywnego życia społecznego, tzw. drugiego obiegu, pełnił w latach 80 . XX wieku i wcześniej, będąc dla wielu migrantów tamtych czasów jedynym pomostem instytucjonalnym do kontaktu z Polską. Polskie parafie w tamtych czasach niejednokrotnie przejmowały role ambasad, zapewniając wiarygodność i wsparcie instytucjonalne wielu formom aktywności kulturalnej, społecznej. Takie znaczenie Kościoła np. w Stanach Zjednoczonych ma długą tradycję - już w latach I i II wojny światowej poprzez polskie parafie odbywały się akcje werbujące ochotników do polskich formacji wojskowych, organizujących pomoc materialną czy też ułatwiającą odnalezienie krewnych.

\footnotetext{
${ }^{31} \mathrm{Za}:$ https://episkopat.pl/duszpasterstwa-polinijne/
} 
Parafia działająca poza granicami Polski oferuje swoje usługi - z racji języka polskiego, w którym prowadzone są msze św. i nabożeństwa - Polakom tymczasowo lub na stałe przebywającym w danym miejscu i zainteresowanych w jakimś stopniu kontaktem. Wobec tego należy zastanowić się, jak wielu Polaków korzysta z wymienionych wyżej form życia, tak religijnego, jak i społeczno-kulturalnego. Chociaż odsetek ten jest znacząco niższy, niż w przypadku Polaków mieszkających w kraju, to dokładniejsza odpowiedź na to pytanie jest niezmiernie trudna do udzielenia, co wynika z kilku podstawowych przyczyn: (1) zazwyczaj nieznana jest dokładna liczba migrantów przebywających w danym miejscu, a wszelkie liczby mają jedynie charakter szacunkowy; ma to związek z płynnym charakterem samej migracji (dotyczy to zwłaszcza najnowszej migracji), przenoszeniem się migrantów pomiędzy różnymi miejscami, powrotami do kraju, a także trybem pracy zarobkowej w systemie zmianowym, co wielu migrantom utrudnia regularny kontakt z parafią w niedziele; (2) nieostra jest sprawa formalnych aspektów obywatelstwa, prawa pobytu i pracy, ewentualnie zameldowania, ale i formalnej przynależności do konkretnej parafii, także w sytuacji małżeństw mieszanych pomiędzy osobami różnych wyznań czy narodowości, a zwłaszcza ich dzieci; (3) różna może być sama subiektywna ocena migrantów dotycząca ich „polskości”, więzi z krajem, i znaczenia, jakie przypisują oni kontaktowi z polską parafią poświęcając na to swój czas, więź ta $\mathrm{z}$ czasem może słabnąć, jednak w wielu przypadkach częstotliwość kontaktu z parafią u Polaków zamieszkujących w danym miejscu od wielu lat może być większa niż wśród przedstawicieli nowszych fal migracji ${ }^{32}$; (4) zamieszkiwanie $w$ danym miejscu nie musi być jednoznaczne $z$ chęcią kontaktu z polską parafią, migranci korzystają także z posługi religijnej w innych parafiach ( $w$ tym również $\mathrm{w}$ takich, gdzie jest polski ksiądz pracujący $\mathrm{w}$ ramach struktur lokalnego Kościoła, bez szczególnych związków ze środowiskiem Polonii); może wreszcie mieć związek ze zjawiskiem występującym w parafiach wielkomiejskich w Polsce - poszukiwania parafii, z którą wierni czują się najbardziej związani emocjonalnie $^{33}$. Wszystko to prowadzi do sytuacji, w której parafia funkcjonująca poza granicami dociera do swoich parafian (Polaków mieszkających w danym regionie) jedynie wtedy, gdy sami parafianie wykażą się chęcią i, niejednokrotnie, niemałym poziomem determinacji, koniecznym, aby znaleźć i utrzymywać następnie więzi z parafią i proponowanymi na jej terenie działaniami.

Jak przebiega adaptacja społeczno-kulturowa migrantów do życia w nowych środowiskach? Próba stworzenia jakiejś typologii prowadzi do dychotomii pomiędzy

${ }^{32}$ Piszę o tym w innym miejscu, por. J. IsAŃsKI, Migracje i transfery.

${ }^{33}$ Zjawisko to określane jest jako churching, w odniesieniu do clubbingu - odwiedzania wielu klubów i barów podczas jednego wieczoru, by wybrać najlepszy. 
przystosowaniem - asymilacją kulturową a integracją z zachowaniem wybranych elementów kultury kraju pochodzenia, ze szczególną rolą parafii, w obrębie której migranci mogą liczyć na różne formy wsparcia. Parafia, dzięki której migrant ma dostęp do kontaktów z rodakami, w której może liczyć na różne formy wsparcia - religijnego, społecznego czy materialnego, jest czynnikiem niejednokrotnie buforującym siłę oddziaływania szoku kulturowego. Chociaż w jej życiu w dzisiejszej migracji w Europie Zachodniej uczestniczy niewielki odsetek Polaków przebywających za granicą, należy podkreślić, że jest to często jedna z instytucji traktowanych jako miejsce, gdzie można uzyskać pomoc w razie potrzeby. W parafii spotykają się ludzie różnych profesji i zajęć, o różnym poziomie wykształcenia i stopnia zintegrowania $z$ lokalnym środowiskiem, a łączy ich oparta o wspólne pochodzenie potrzeba uczestniczenia w różnych formach życia religijnego i korzystania przy tej okazji ze wsparcia społecznego.

Należy dodać, iż funkcjonujące poza granicami Polski parafie muszą mierzyć się także z wyzwaniami wielokulturowego i wieloreligijnego środowiska (w tym z postępującą sekularyzacją prowadzącą nie tylko do zmniejszania się liczby wiernych, ale i innych w stosunku do polskiego klimatu prowadzenia działalności duszpasterskiej). Chociaż chrześcijaństwo jest najliczniejszą religią świata, w 2015 roku obejmowało 31,2\% ludności świata (wobec 24,1\% muzułmanów i 15,1\% hinduistów), to w ostatnich latach wzrasta odsetek osób deklarujących się jako areligijni. Na dynamiczny wzrost liczebny tej kategorii wpływa szereg czynników składających się na procesy sekularyzacji, widoczne szczególnie w rozwiniętych gospodarczo krajach Europy Zachodniej, do której wyjechała zdecydowana większość polskich migrantów w ostatnich latach. W prognozie Pew Research Centre do roku 2050 nastąpi spadek liczby chrześcijan, chociaż warto zaznaczyć, że liczba chrześcijan w skali świata wzrośnie, głównie w wyniku wzrostu liczby ludności w Afryce Subsaharyjskiej. W Europie jest wzrost też odsetek wspomnianych już ateistów $\mathrm{z}$ około $12 \%$ do $14 \%$. Należy zauważyć, że dynamicznym zmianom podlega także sama zbiorowość chrześcijan, nie tylko ze względu na różne denominacje i tradycje, ale i - w krajach zachodnich - rosnący odsetek osób deklarujących swój coraz luźniejszy związek z religią. We wszystkich krajach Europy Zachodniej widoczny jest spadek odsetka osób religijnych; w wielu z nich prawie połowa mieszkańców deklaruje się jako ateiści. I tak w Holandii 48\% mieszkańców deklaruje się jako ateiści, w Norwegii - 43\%, w Szwecji - 42\%, w Belgii - 38\%; dla porównania w Polsce 3\% respondentów w badaniu religijności CBOS z 2014 roku zadeklarowało się jako ateiści. Wspomniany już luźniejszy związek z religią oznacza w praktyce stopniowe odchodzenie od celebrowania religijnych sakramentów, ale też zwyczajów i świąt; powstaje w ten sposób kategoria niepraktykujących chrześcijan, która obejmuje 68\% chrześcijan w Finlandii, 55\% w Wielkiej Brytanii i Danii, 52\% 
w Austrii, ponad 40\% w Belgii, Francji, Niemczech, Irlandii, Portugalii, Hiszpanii, Szwecji i Szwajcarii. Warto dodać, że najczęściej deklarowaną przez respondentów przyczyną utraty wiary jest „stopniowe odchodzenie od religii w codziennym życiu” (68\% wskazań), kolejnymi: niezgoda z religijnymi pryncypiami i zasadami w życiu społecznym (58\% odpowiedzi), utrata wiary w nauczanie religijne (54\%), skandale w obrębie religijnych instytucji (53\%), a wśród rzadziej wskazywanych - ,niewypełnianie przez religię moich potrzeb religijnych" $(26 \%)$, ,zawiedzenie przez religię w momencie, gdy jej potrzebowałem" (21\%). Religia z jej moralnym przesłaniem staje się coraz mniej istotnym regulatorem życia społecznego, ustępując miejsca wielu innym okołoreligijnym praktykom, jak ,horoskopy” (wskazywane przez 13\% badanych w krajach zachodniej Europy), praktyki medytacyjne (19\% wskazań), wiara w reinkarnację $(20 \%)$, astrologię $(23 \%)$, duchową moc jogi $(26 \%)$ czy też w przeznaczenie $(34 \%)^{34}$. W badaniach religijności realizowanych w Polsce widoczny jest z kolei wzrost odsetka osób wierzących „na swój własny sposób”. Liczebność tej kategorii w wielu przypadkach przekracza liczbę osób ściśle stosujących się do wskazań Kościoła i przykazań: 52\% wobec 39\% w badaniu CBOS z 2014 roku.

W związku ze społeczno-demograficznym profilem typowego migranta potencjalny odbiorca parafialnej oferty jest młody (młodszy niż w przypadku osób biorących udział w życiu parafialnym na terenie Polski). Procent osób, które kiedykolwiek były za granicą, w przedziałach wiekowych przedstawia się następująco: $18-24$ lat $-70 \%$, 25-34 lat - 82\%, 35-44 lat - 79\%, 45-54 lat - 82\%, 55-64 lat $-73 \%$ i 65 lat i więcej $-54 \%{ }^{35}$. W 2015 roku celem wyjazdów 27\% Polaków była praca (wzrost z poziomu 18\% w 2004 roku). To kolejne wyzwanie - zarobkowy cel wyjazdu oznacza, zazwyczaj, integrację z lokalnym środowiskiem pracy w miejscu przyjazdu, niekoniecznie jednak integrację z innymi formami aktywności społecznej, kulturalnej czy religijnej. Można powiedzieć, że składa się na to wiele czynników, od charakteru podejmowanych przez migrantów zajęć (często są to zajęcia niewymagające specjalistycznych kwalifikacji, na różnych etapach procesu produkcyjnego, przy pakowaniu, w systemie zmianowym). Warto dodać, że w 2016 roku już co piąty Polak mieszkający aktualnie w Polsce deklarował, że pracował zarobkowo przynajmniej raz za granicą, a 12\% zadeklarowało, że było to doświadczenie pracy w ostatnich dziesięciu latach. W tej grupie widoczna jest przewaga liczebna mężczyzn nad kobietami (14\% z nich wobec $10 \%$ kobiet ma zagraniczne doświadczenie zarobkowe $\mathrm{z}$ ostatnich lat). Natomiast najwyższy od-

34 Wszystkie dane za: Pew Research Center, Being Christian in Western Europe, 2018, http:// www.pewforum.org/2018/05/29/being-christian-in-western-europe/

${ }^{35}$ Dane za: CBOS, O wyjazdach zagranicznych i znajomości języków obcych, oprac. R. Boguszewski, 2016, https://www.cbos.pl/SPISKOM.POL/2016/K_005_16.PDF 
setek osób z takimi doświadczeniami jest w grupie wiekowej 25-34 lat - wynosi $27 \%$. Wśród tych wyjazdów dominowały krótkotrwałe - wyjazdy na kilka miesięcy i krótsze stanowiły $63 \%$ wszystkich wyjazdów zarobkowych, a wyjazdy na rok lub dłużej to 37\%. Zarobkowa intensywność krótkich wyjazdów (nazwanych w jednej z popularnych typologii: chomikowaniem) również wydaje się nie sprzyjać głębszemu zaangażowaniu w życie religijne poza granicami $\mathrm{kraju}^{36}$.

Migracyjna aktywność Polaków oznacza ich bezpośredni kontakt ze społeczeństwami o innych wzorach religijności, innych zwyczajach świątecznych czy też innym stopniu obecności religijnych wątków w życiu codziennym, a także ekspozycją na wielość religijnych i okołoreligijnych treści. Wzrastająca liczba migrantów znacząco wpływa także na przemiany religijności w Polsce. Migranci utrzymują stałe kontakty z bliskimi i rodziną pozostałą w kraju, wielu migrantów wielokrotnie też odwiedza Polskę, traktując swoje wyjazdy raczej jako okazję do doraźnej poprawy sytuacji finansowej, niż stałą zmianę miejsca zamieszkania. Obecnie poza granicami Polski mieszka, według szacunków Głównego Urzędu Statystycznego, około 2,5 miliona Polaków, a ponad 10\% gospodarstw domowych w Polsce ma w swoim składzie kogoś mieszkającego poza granicami, przy czym w większości przypadków jest to osoba przebywająca za granicą dłużej niż rok (w regionach południowym i południowo-wschodnim było to ponad $15 \%$, dane za Głównym Urzędem Statystycznym). Aktywność wyjazdowa zagraniczna, zarówno zarobkowa, jak i o charakterze wakacyjnym, jest znaczna, niemal 3/4 Polaków było co najmniej raz w życiu poza granicami kraju, przy czym, według danych CBOS, w kategorii wiekowej 25-34 odsetek ten wynosi 82\%.

Funkcjonująca poza granicami Polski parafia kierująca swoje duszpasterskie propozycje dla Polaków, zwłaszcza przebywających za granicą od niedawna, znajduje się w innych realiach społecznych w porównaniu do parafii działających w Polsce. Inne ramy działalności wyznacza szereg wspominanych warunków, by przypomnieć tymczasowość i przejściowość, widoczne w pewnym stopniu w miastach i w mniejszym w obszarach niezurbanizowanych, które są stałym elementem parafii działających za granicą. Typowy parafianin poza granicami kraju jest młodszy i prawdopodobnie bardziej zajęty pracą zarobkową; jest też lepiej wykształcony, bogatszy, znający języki obce oraz utrzymujący więzi z krajem pochodzenia; przede wszystkim jednak - mniej religijny, co pokazują badania. O ile na podstawie badań statystycznych można powiedzieć, że połowa Polaków uczęszcza regularnie na niedzielną mszę św. (w miastach odsetek ten jest o kilka - kilkanaście punktów procentowych niższy), o tyle przeciętny parafianin-migrant pojawia się w kościele rzadziej.

36 Dane za: CBOS, Praca za granica, oprac. A. Cybulska, 2016, https://www.cbos.pl/SPISKOM. POL/2016/K_175_16.PDF 


\section{BIBLIOGRAFIA}

Balicki J., Bieniecki M., Udział Kościoła katolickiego w Polityce migracyjnej RP aspekty społeczno-charytatywne, w: Współczesne polskie migracje: strategie - skutki społeczne - reakcja państwa, red. M. Lesińska, M. Okólski, Warszawa 2013.

CAstles S., Mark J.M., The age of migration. International population movements in the modern world, New York: Pelgrave Macmillan 2009.

Chalasiński J., Polonia amerykańska, w: F. ZnANiecki, W. Thomas, Chłop polski w Europie i Ameryce, t. I: Organizacja grupy pierwotnej, Warszawa: Ludowa Spółdzielnia Wydawnicza 1976.

Coleman J., Social Capital in the Creation of Human Capital, "The American Journal of Sociology" 94 (1988).

Dzwonkowski R., Papież Jan Paweł II. Misja Polonii i Emigracji, Warszawa: Wydawnictwo Ministerstwa Spraw Zagranicznych 2016.

Erdmans M.P., Opposite Poles. Immigrants and Ethnics in Polish Chicago 1976-1990, Pennsylvania: Penn State University Press 1998.

FirLIT E., Wspólnotowy wymiar religijności, w: Postawy społeczno-religijne Polaków 1991-2012, red. L. Adamczuk, E. Firlit, W. Zdaniewicz, Warszawa: Instytut Statystyki Kościoła Katolickiego SAC 2013.

GrabowsKa I., OKólSKI M., Emigracja ostatnia?, Warszawa: PWN 2009.

Granacki V., Images of America. Chicago's Polish Downtown, Charleston: Arcadia Publishing 2004.

Gudaszewski G., Dominicantes i communicantes - religijne praktyki niedzielne, w: Rocznik Statystyczny. Kościół katolicki w Polsce 1991-2011, red. P. Ciecieląg, P. Łysoń, W. Sadłoń, W. Zdaniewicz, Warszawa: Instytut Statystyki Kościoła Katolickiego SAC, GUS, Departament Badań Społecznych i Warunków Życia Zakład Wydawnictw Statystycznych 2014.

IsAŃSKI J., Migracje i transfery kapitału społecznego, Poznań: Wydawnictwo Naukowe Uniwersytetu im. Adama Mickiewicza 2015.

JANOWSKA H., Emigracja zarobkowa z Polski 1918-1939, Warszawa: PWN 1981.

JAŹWIŃSKA-MOTYLSKa E. (red.), Kariery i mobilność społeczno-zawodowa migrantów poakcesyjnych, „CMR Working Papers” 2013, nr 65(123).

KWAK A., Współczesne związki heteroseksualne, małżeństwa (dobrowolnie bezdzietne), kohabitacja, LAT, Warszawa: Wydawnictwo Akademickie ŻAK 2014.

ŁYsoŃ P., Terytorialne zróżnicowanie wybranych wskaźników religijności, w: Rocznik Statystyczny. Kościół katolicki w Polsce 1991-2011, red. P. Ciecieląg, P. Łysoń, W. Sadłoń, W. Zdaniewicz, Warszawa: Instytut Statystyki Kościoła Katolickiego SAC, GUS, Departament Badań Społecznych i Warunków Życia Zakład Wydawnictw Statystycznych 2014.

Necel W., Katolickie duszpasterstwo na emigracji, w: Rocznik Statystyczny. Kościół katolicki w Polsce 1991-2011, red. P. Ciecieląg, P. Łysoń, W. Sadłoń, W. Zdaniewicz, Warszawa: Instytut Statystyki Kościoła Katolickiego SAC, GUS, Departament Badań Społecznych i Warunków Życia Zakład Wydawnictw Statystycznych 2014. 
OKóLSKI M., Costs and benefits of migration for Central European countries, „CMR Working Papers" 2006, nr 7(65).

Papieska Rada Ds. DuszPasterstwa Migrantów i Podróżujących. Instrukcja Erga migrantes caritas Christi - miłość Chrystusa do migrantów, 2004.

Parafia jako rzeczywistość wielowymiarowa, red. J. Baniak, Poznań: Wydawnictwo UAM 2003.

Portes A., Rumbaut R.G., Immigrant America. A Portrait. Third Edition. Revised, Expanded and Updated, Los Angeles-London: University of California Press 2006.

Postawy społeczno-religijne Polaków 1991-2012, red. L. Adamczuk, E. Firlit, W. Zdaniewicz Warszawa: Instytut Statystyki Kościoła Katolickiego SAC 2013.

SADŁoŃ W., Religijny kapitał społeczny. Kapitał społeczny a Kościół katolicki w społecznościach lokalnych w Polsce, Saarbrücken: Wydawnictwo Bezkresy Wiedzy 2014.

SADŁoŃ W., Społeczny potencjał parafii. Działalność przyparafialnych organizacji Kościoła katolickiego w Polsce w 2012 r., Warszawa: Główny Urząd Statystyczny, Departament Badań Społecznych i Warunków Życia oraz Instytut Statystyki Kościoła Katolickiego SAC 2014.

SADŁoŃ W., Kościelny trzeci sektor w Polsce oraz działalność charytatywna, w: Rocznik Statystyczny. Kościół katolicki w Polsce 1991-2011, red. P. Ciecieląg, P. Łysoń, W. Sadłon, W. Zdaniewicz, Warszawa: Instytut Statystyki Kościoła Katolickiego SAC, GUS, Departament Badań Społecznych i Warunków Życia Zakład Wydawnictw Statystycznych 2014.

Selling one's favourite piano to emigrate. Mobility patterns in Central Europe at the beginning of the 21st century, red. J. Isański, P. Luczys, Cambridge: Cambridge Scholars Publishing 2011.

SeredyŃSKa-Abou EId R., Polish on-line communities in the UK, w: Selling one's favourite piano to emigrate. Mobility patterns in Central Europe at the beginning of the 21st century, red. J. Isański, P. Luczys, Cambridge: Cambridge Scholars Publishing 2011.

Sumption M., Somerville W., The UK's New Europeans. Progress and challenges five years after accession, 2009 [online], http://www.migrationpolicy.org/research/uks-new-europeans-progress-and-challenges-five-years-after-accession.

Vershinina N., Barrett R., Meyer M., Forms of capital, intra-ethnic variation and Polish entrepreneurs in Leicester, „Work, Employment and Society” 2011, nr 25(1), s. 101-117.

WACH J., Socjologia religii, Warszawa: Książka i Wiedza 1961.

White A., Ryan L., Polish 'Temporary' Migration: The Formation and Significance of Social Networks, "Europe-Asia Studies" 60 (2008), nr 9.

WrZESIŃsKI W., Polskie migracje w XIX i XX wieku, w: Migracje: dzieje, typologia, definicje, red. A. Furdal, W. Wysoczański, Wrocław 2006.

\section{Raporty z badań}

Pew Research Center, The Changing Global Religious Landscape, 2017, http://www. pewforum. org/2017/04/05/the-changing-global-religious-landscape/ 
Pew Research Center, Being Christian in Western Europe, 2018, http://www.pewforum. org/ 2018/05/29/being-christian-in-western-europe/

Główny Urząd Statystyczny, 2011, Gospodarstwa domowe i rodziny z migrantami - NSP 2011, http://stat.gov.pl/obszary-tematyczne/ludnosc/migracje-zagraniczne-ludnosci/ gospodarstwa-domowe-i-rodziny-z-migrantami-nsp-2011,12,1.html

Główny Urząd Statystyczny, 2018, Ludność. Stan i struktura oraz ruch naturalny w przekroju terytorialnym w 2018 r. Stan w dniu 30 VI: http://stat.gov.pl/obszary-tematyczne/ ludnosc/ludnosc/ludnosc-stan-i-struktura-oraz-ruch-naturalny-w-przekroju-terytorialnym-w-2018-r-stan-w-dniu-30-vi,6,24.html

Centrum Badania Opinii Społecznej, Społeczna percepcja rzeczywistości parafialnej, oprac. Natalia Hipsz, 2014, https://www.cbos.pl/SPISKOM.POL/2014/K_163_14.PDF

Centrum Badania Opinii Społecznej, Lokalna parafia - jej społeczne znaczenie i funkcje, oprac. Rafał Boguszewski, 2014, https://www.cbos.pl/SPISKOM.POL/2014/K_158_14. PDF

Centrum Badania Opinii Społecznej, O wyjazdach zagranicznych i znajomości języków obcych, oprac. Rafał Boguszewski, 2016, https://www.cbos.pl/SPISKOM. POL/2016/K_005_16.PDF

Centrum Badania Opinii Społecznej, Praca za granicą, oprac. Agnieszka Cybulska, 2016, https://www.cbos.pl/SPISKOM.POL/2016/K_175_16.PDF

\section{ŻYCIE SPOŁECZNE W KONTEKŚCIE MIGRACYJNYM \\ PARAFIA JAKO OŚRODEK ŻYCIA RELIGIJNO-SPOŁECZNEGO \\ POZA GRANICAMI POLSKI}

\section{Streszczenie}

W tekście zawarte są informacje na temat społeczno-religijnej roli parafii działającej w środowisku migracyjnym. Na przykładzie zaangażowania parafian w różne formy parafialnej aktywności przedstawiony jest potencjał parafii jako ośrodka życia nie tylko religijnego, ale także społecznego, kulturalnego czy ekonomicznego związanego ze wspólnym pochodzeniem etnicznym. Podane informacje zilustrowane są danymi z ogólnodostępnych badań socjologicznych dotyczących religijności, aktywności społecznej w parafii oraz prognoz dotyczących przyszłego kierunku przemian w tym zakresie.

Slowa kluczowe: migracje; parafia; życie społeczne w parafii; aktywność parafian. 


\section{SOCIAL LIFE IN AN EMIGRANT CONTEXT \\ PARISH AS A CENTER OF SOCIO-RELIGIOUS LIFE OUTSIDE OF POLAND}

\section{Sum m a ry}

The text contains information on the socio-religious role of a parish working in a migrant comunity. On the example of parishioners' involvement in various forms of parish activities, the potential of the parish is presented as a center of life not only in a religious terms, but also in social, cultural or economic issues connected based on ethnic background. The mentioned information are illustrated with data from publicly available sociological research on religiosity, social activities in parishes and forecasts for the future direction of changes in these areas.

Key words: migrations; parish; social life in a parish; activities of parishioners 